The third section of the book deals with the practical application of the Clean Air Act, and the reader quickly realizes that much of it is based on Mr. Gilpin's personal experience. It is this section that the student public health inspector will find invaluable.

The final section deals with other major problems such as pollution from the iron and steel works, the ceramic industry and power stations. It also includes a section on motor vehicle pollution-a subject which cannot be ignored by anyone concerned with clean air in the future. The final chapter is a short one on odour control, and this could have merited some extension, as problems of odours can be among the most intractable of any found in the air pollution field, if the solution is to be both acceptable and economic.

The book is well written, clearly presented and the references are both recent and adequate. Although the intention was to quote temperatures in both Fahrenheit and centigrade units, in several places the centigrade figures have been omitted.

The production of this book must have involved Mr. Gilpin in a tremendous amount of work, and one of his rewards will be that his book will be quoted as a reference book on air pollution for many years to come.

\section{E. REED}

\section{BACTERIAL LIPIDS}

\section{Les Lipides Bactériens}

Isolement - Composition - Propriétés. By Joan Asselineau. (Actualités Scientifiques et Industrielles No. 1297.) Pp. xvi+350. (Paris: Hermann, 1962.) 36 N.F.

TES Lipides Bactériens is a member of a series of mono$L$ graphs on the chemistry of selected groups of natural products under tho general editorship of Edgar Lederer. This volume is particularly to be welcomed as it gathors together the confused and scattered literature of a subject that has not previously been adequately dealt with in the form of a monograph, and it will sorve as a starting-point for anyone wishing to gain a clear idea of what has already beon achieved in a notably difficult experimental field. The author, a former colleague of Lederer, has presented a clearly written and well-ordered account which conveys in numerous ways his own shrewd assessments of methods and results. At the outset the author gives the impression that he will regard as lipids substances containing in their molecules an aliphatic chain of at least ten carbon atoms irrespective of substituents on the chain, but this classification is not adhered to rigidly.

The first section deals with methods for the cultivation of bacteria, the extraction and fractionation of their lipids, physicochemical methods of analysis, degradative and synthetic methods. The second section gives a systematic description of specific constituents of bacterial lipids, and the third similarly treats the more complex components, such as the waxes, phosphatides, glycolipids, peptidolipids, peptido-glycolipids, and lipopolysaccharides, and their localization within the bacterial cell. A fourth section considers the lipids of various species of bacteria, but, apart from the much-studied acid-fast organisms, the available knowledge concerning tho lipids of many widely distributed and important pathogens is as yet very fragmentary indeed. A final short section describes the biological properties of bactorial lipids under the headings of the effects they produce.

In the prefaco to Les Lipides Bactériens, Lederer pays tribute to the impressive work of R. J. Anderson, of Yale University, carried out before the availability of the modern methods which are taken so much for granted. The French workers are now themselves making frequent and important advances in this difficult field, and Asselineau's book can best be regarded as a comprehensive interim progress report, which is rounded off with a generous bibliography reflecting a refreshingly catholic outlook on many diverse facets of the subject.

\section{J. WALKER}

\section{FORMATION OF PUBLIC POLICY}

Power, Politics and People

The Collected Essays of C. Wright Mills. Edited and with an Introduction by Irving Louis Horowitz. Pp. $\mathrm{xi}+657$. (London and New York: Oxford University Press, 1963.) 52s. 6d. net.

$T$

HE thirty essays and four reviews, one of the essays being virtually a review of James Burnham's The Managerial Revolution, collected in this volume were written over the years 1939-60. They are arranged in four parts, of which the successive themos are the concept of power; politics, in the sense of the long-term implications of liberalism and conservatism, and liberalism and Marxism in the modern world; people, embracing the individual problems of living in modern society and communities; knowledge, more particularly the sociology of knowledge. In his introduction, the editor, I. L. Horowitz, claims that these essays embody all the most important statements about modern culture and society of one whom he describes as the greatest sociologist that the United States has produced. If that claim seems premature, the comparative freedom from jargon of the book may well predispose the reader to concede that Mr. Mills is one of the best American writers on that theme. The essays are well provided with bibliographical references, and for its comments on Tawney, Durkheim, Mannheim, Weber and others the book is often rewarding.

Nevertheless, the title of the book could well lead some readers to expect too much. On some central problems of to-day, of the relations between power and knowledge, as exemplified in the problem of science and Government and of the place of the expert adviser, the book throws little light and the subtler nuances of the relation between power and influence are not discussed. Something indeed is said of pressure groups and, at least by implication, of the opportunities and responsibilities of the professional association, but on politics generally it is less satisfying than J. D. B. Miller's The Nature of Politics (Nature, 196, 301; 1962).

For all that, there is much that is stimulating and much to ponder in a British context, even when, as in the essay on "The Structure of Power in American Society", Mills writes in an American setting. Consider, for example, his criteria for political structure of a modern democratic state: the existence of a public constituting a forum within which the politics of real issues is enacted; a civil service firmly linked with the world of knowledge and sensibility, and consisting of men truly independent, in careers and aspirations, of any private or sectional interest; rationally responsible parties debating the issues openly and clearly; an intelligentsia, inside as well as outside the universities, carrying on the debate, and whose work is relevant to and influential among parties and movements; free associations or groups. Mr. Mills did not find all these formations ascendant in the United States, but their presence or absence largely determines the extent to which the public interest is truly served. Could one be sure that they are in the ascendant in Britain in the present debates on education, or the structure of Government and in the organization of science and technology?

Again, writing on the social role of the intellectual, after stressing the vital importance of effective means of communication, of a material basis for initiative and intellectual freedom, Mills stresses the dependence, in modern society, of both freedom and security on organized responsibility. He writes refreshingly on the unity of work and leisure, arguing that the problem of leisure is that of so heightening the qualities of experience in all 